\title{
A SNaPshot Assay for Determination of the Mannose-Binding Lectin Gene Variants and an Algorithm for Calculation of Haplogenotype Combinations
}

\author{
Jana Mrazkova ${ }^{1,2} \mathbb{D}$, Petr Sistek ${ }^{3} \mathbb{D}$, Jan Lochman ${ }^{1,4}$, Lydie Izakovicova Holla 1,2 ${ }^{\mathbb{D}}$, Zdenek Danek ${ }^{1,2,5}$ \\ and Petra Borilova Linhartova $1,2,5,6,7, *$ (D)
}

Citation: Mrazkova, J.; Sistek, P.; Lochman, J.; Izakovicova Holla, L.; Danek, Z.; Borilova Linhartova, P. A SNaPshot Assay for Determination of the Mannose-Binding Lectin Gene Variants and an Algorithm for Calculation of Haplogenotype Combinations. Diagnostics 2021, 11, 301. https://doi.org/10.3390/ diagnostics11020301

Received: 2 November 2020 Accepted: 11 February 2021 Published: 13 February 2021

Publisher's Note: MDPI stays neutral with regard to jurisdictional claims in published maps and institutional affiliations.

Copyright: (c) 2021 by the authors. Licensee MDPI, Basel, Switzerland. This article is an open access article distributed under the terms and conditions of the Creative Commons Attribution (CC BY) license (https:/ / creativecommons.org/licenses/by/ $4.0 /)$.
1 Department of Pathophysiology, Faculty of Medicine, Masaryk University, Kamenice 753/5, 62500 Brno, Czech Republic; jmrazkova.pracovni@gmail.com (J.M.); Jlochman@seznam.cz (J.L.); holla@med.muni.cz (L.I.H.); danek002@gmail.com (Z.D.)

2 Department of Stomatology, Institution Shared with St. Anne's Faculty Hospital and Faculty of Medicine, Masaryk University, Pekarska 664/53, 65691 Brno, Czech Republic

3 Secondary Technical School Brno, Purkynova, a Contributory Organization, Purkynova 97, 61200 Brno, Czech Republic; sistek.petr@email.cz

4 Department of Biochemistry, Faculty of Science, Masaryk University, Kotlarska 267/2, 61137 Brno, Czech Republic

5 Clinic of Maxillofacial Surgery, Institution Shared with the University Hospital Brno, Faculty of Medicine, Masaryk University, Jihlavska 20, 62500 Brno, Czech Republic

6 Institute of Medical Genetics and Genomics, Faculty of Medicine, Masaryk University, Kamenice 753/5, 62500 Brno, Czech Republic

7 Department of Molecular Pharmacy, Faculty of Pharmacy, Masaryk University, Palackeho tr. 1946/1, 61200 Brno, Czech Republic

* Correspondence: peta.linhartova@gmail.com; Tel.: +420-775-393-703

\begin{abstract}
Mannose-binding lectin (MBL) deficiency caused by the variability in the MBL2 gene is responsible for the susceptibility to and severity of various infectious and autoimmune diseases. A combination of six single nucleotide polymorphisms (SNPs) has a major impact on MBL levels in circulation. The aim of this study is to design and validate a sensitive and economical method for determining MBL2 haplogenotypes. The SNaPshot assay is designed and optimized to genotype six SNPs (rs1800451, rs1800450, rs5030737, rs7095891, rs7096206, rs11003125) and is validated by comparing results with Sanger sequencing. Additionally, an algorithm for online calculation of haplogenotype combinations from the determined genotypes is developed. Three hundred and twenty-eight DNA samples from healthy individuals from the Czech population are genotyped. Minor allele frequencies (MAFs) in the Czech population are in accordance with those present in the European population. The SNaPshot assay for MBL2 genotyping is a high-throughput, cost-effective technique that can be used in further genetic-association studies or in clinical practice. Moreover, a freely available online application for the calculation of haplogenotypes from SNPs is developed within the scope of this project.
\end{abstract}

Keywords: mannose-binding lectin; mannose-binding lectin gene (MBL2); SNaPshot assay; single nucleotide polymorphism; genotyping; Haplogenotype Calculator; haplogenotypes

\section{Introduction}

Mannose-binding lectin (MBL, also known as mannose-binding protein, mannanbinding protein/lectin, Collectin 1, MBP1, or mannose-binding protein C) is a crucial part of innate immunity. It is classified as an acute-phase protein because its plasma level increases after the onset of inflammation. MBL belongs to a group of soluble pattern-recognition receptors that can recognize pathogen-associated molecular patterns and damage-associated molecular patterns released from activated cells, cells undergoing apoptosis or necrosis, or host cells with altered surface glycosylation patterns related to cancer phenotypes [1-5]. 
MBL trimers and tetramers are the forms most common in blood circulation due to their high effectiveness in complement activation after interaction with MBL-associated serine proteases (MASP 1, -2, -3) [6-9]. Furthermore, MBL works as an opsonin and enables phagocytosis independently on the complement $[1,4]$.

The concentration of the functional MBL in blood circulation is affected by the MBL2 gene variant located on chromosome 10q11.2-21. Alleles B (rs1800450, NM_000242.2:c.161G>A), C (rs1800451, NM_000242.2:c.170G>A) or D (rs5030737, NM_000242.2:c.154C>T), possessing single nucleotide polymorphisms (SNPs) in exon 1, cause amino acid substitution of Gly54Asp, Gly57Glu, or Arg52Cys, respectively. These variants lead to the production of a structurally impaired protein. As a result of the substitutions higher MBL oligomers disintegrate more rapidly into lower oligomers, which are no longer capable of activating the complement system. These alleles are summarily called alleles $\mathrm{O}$, whereas the allele without substitution (normal allele) is called allele A. Alleles H/L (rs11003125) and X/Y (rs7096206) carrying SNPs localized in the promoter region (NM_000242.2:c.-619C>G and NM_000242.2:c.-290C>G, respectively), and allele P/Q (rs7095891) with the SNP in the 5' untranslated region (5'UTR) of exon 1 (NM_000242.2:c.-66C>T), alter MBL2 transcription and translation, directly affecting the MBL plasma level $[8,10]$.

Due to strong linkage disequilibrium (LD) among the six SNPs and variation of these SNPs' frequencies among ethnic groups, only seven MBL secretor haplotypes (allele combinations) are relatively common. HYPA and LYQA haplotypes are associated with high MBL serum levels, LYPA with intermediate levels, and LXPA with low MBL production. Defect haplotypes LYPB, LYQC and HYPD are responsible for expressing undetectable amounts of MBL [10,11]. Nevertheless, the MBL level in circulation depends on a combination of two haplotypes; for example, the HYPA/LXPA haplogenotype is responsible for medium MBL levels while LYPB, LYQC or HYPD combined with LYPA leads to low MBL levels in the serum [12]. MBL deficiency (a common human immunodeficiency, 5-30\% of the population is affected) has been associated with increased susceptibility toward infectious diseases and autoimmune diseases [13]. Therefore, determining genotypes of all six SNPs and the resulting haplogenotypes is necessary for predicting the MBL phenotype.

The SNaPshot assay is a minisequencing method widely used for simultaneous detection of polymorphisms in individual genes [14,15] or the whole genome [16]. The assay is sensitive and straightforward, and the results can be automatically evaluated using software. Therefore, this method is very well suited for multiple SNP genotyping in the MBL2 gene.

The aim of this work is to develop a low cost, accurate, and reliable method for genotyping six functional SNPs in the MBL2 gene that could be utilized both in research and clinical practice, and to use this method for the genotyping of 328 samples of healthy individuals from the Czech population. Furthermore, we develop a custom-made online application for the calculation of haplogenotypes in this study.

\section{Materials and Methods}

\subsection{Study Subjects and Sampling}

To optimize the originally designed SNaPshot assay, subjects meeting the inclusion criteria were selected from the pool of patients of the Institutions shared with St. Anne's Faculty Hospital and Faculty of Medicine, Masaryk University, Brno, Czech Republic. Inclusion criteria for this study were: adult (aged 18 years and higher), Czech nationality, systemic health, and willingness to participate. Exclusion criteria comprised the inability to give consent, blood relationship to another participant, history of systemic diseases (such as diabetes mellitus, coronary artery diseases, malignancies, immunodeficiency disorders), immunosuppression attributable to medication, or concurrent illness.

Three hundred and twenty-eight individuals with good systemic health (mean age \pm standard deviation of $34.0 \pm 13.5$ years, 192 women and 136 men) were enrolled in this study; for demographic data, see Table 1. Peripheral blood was collected from each subject in a tube 
containing $0.5 \mathrm{M}$ ethylenediaminetetraacetic acid (EDTA) and stored at $-20{ }^{\circ} \mathrm{C}$ within $30 \mathrm{~min}$ of collection.

Table 1. Demographic data of 328 individuals with good systemic health who enrolled in this study; all were selected from the Czech population.

\begin{tabular}{cccc}
\hline Characteristics & $\begin{array}{c}\boldsymbol{n = 3 2 8} \\
\text { Total }\end{array}$ & $\begin{array}{c}\boldsymbol{n = 1 9 2} \\
\text { Female }\end{array}$ & $\begin{array}{c}\boldsymbol{n}=\mathbf{1 3 6} \\
\text { Male }\end{array}$ \\
\hline Age (mean \pm SD, & $34.0 \pm 13.5$, & $34.0 \pm 14.3$, & $34.1 \pm 12.2$, \\
median, IQR) in years & $30.0,23.0-43.0$ & $27.0,22.0-44.5$ & $31.0,25.0-41.0$ \\
\hline
\end{tabular}

$\mathrm{IQR}$, interquartile range; $n$, number of subjects; $\mathrm{SD}$, standard deviation.

\subsection{DNA Isolation}

Genomic DNA was isolated from peripheral blood leukocytes using proteinase K digestion of cells and isopropanol-phenol-chloroform DNA extraction according to the standard protocol [17]. DNA concentration and purity were determined using a spectrophotometer NanoDrop 1000 (Thermo Fisher Scientific, Waltham, MA, USA) and all DNA samples were diluted to working concentrations of $50 \mathrm{ng} / \mu \mathrm{L}$.

\subsection{SNaPshot Assay}

The SNaPshot assay was applied for simultaneous determination of six single nucleotide polymorphisms (SNPs) in the MBL2 gene (rs11003125, rs7096206, rs7095891, rs1800450, rs1800451, rs5030737). The part of the MBL2 sequence carrying all SNPs of interest was determined using commercial Sanger sequencing (Eurofins Genomics Germany $\mathrm{GmbH}$, Ebersberg, Germany) in 8 samples randomly chosen from the sample pool. These samples served as controls for the optimization of the SNaPshot assay.

\subsubsection{Primer Design}

Forward and reverse primers, 5'-CTGTAAACAGATTCCCCCAGTA-3' and 5'-GGAGGAT TCAAGGCAAGTTTTC-3', respectively, used in the amplification polymerase chain reaction (PCR), were originally designed in the Primer3Plus program (https://primer3plus. com/cgi-bin/dev/primer3plus.cgi (accessed on 2 November 2020)). The potential formation of homo/heterodimers and hairpin structures were checked by the IDT OligoAnalyzer (https: / / eu.idtdna.com/calc/analyzer (accessed on 2 November 2020)); the specificity of selected primers was tested using NCBI Primer-BLAST (https:/ / www.ncbi.nlm.nih.gov/tools / primer-blast/ (accessed on 2 November 2020)). One primer specific for single-base extension (SBE) reaction was designed for each single nucleotide polymorphism (SNP) (rs11003125, rs7096206, rs7095891, rs1800450, rs1800451, rs5030737) using a sequence from the NCBI dbSNP database (https: / / www.ncbi.nlm.nih.gov / projects/SNP/ (accessed on 2 November 2020)). Poly-T tails of different lengths were added to each SBE primer, and analysis of hairpin and dimer formation was performed. SBE primers were commercially synthesized and purified by high-performance liquid chromatography (Integrated DNA Technologies, Leuven, Belgium). The information about primers is listed in Table 2. 
Table 2. Primers used in the single-base extension (SBE) reaction for determining the mannose-binding lectin gene (MBL2) single nucleotide polymorphisms (SNPs).

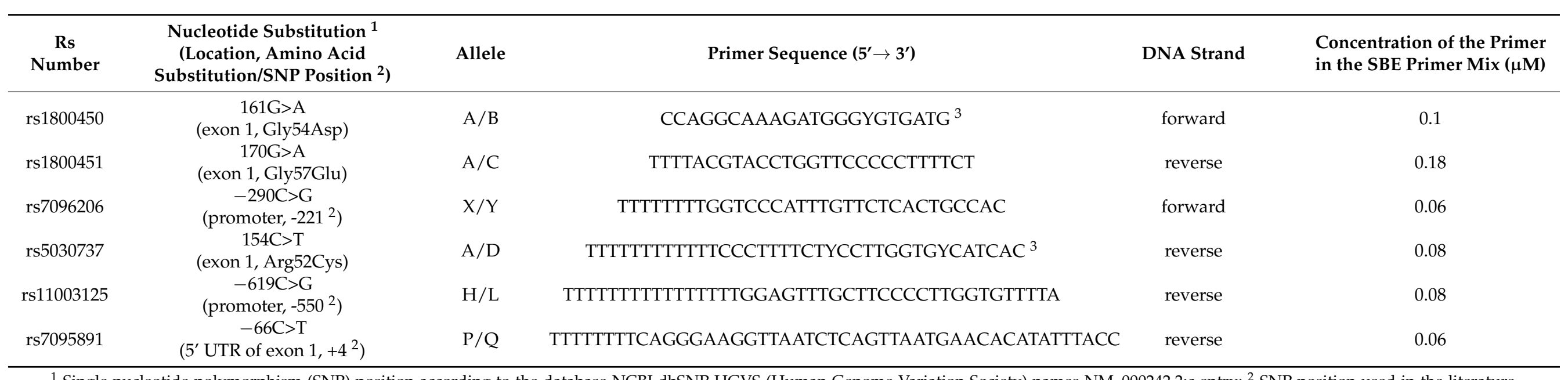

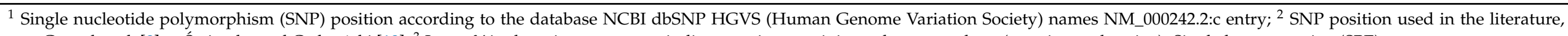
e.g., Garred et al. [8] or Świerzko and Cedzyński [18]; ${ }^{3}$ Letter Y in the primer sequence indicates a site containing a degenerate base (cytosine or thymine). Single-base extension (SBE). 


\subsubsection{Amplification PCR}

Ten microliters of the PCR mixture contained a $1 \times$ Taq buffer with $\left(\mathrm{NH}_{4}\right)_{2} \mathrm{SO}_{4}$ and without $\mathrm{MgCl}_{2}$, a $0.3 \mathrm{mM}$ concentration of each deoxynucleotide (dNTP), a $0.25 \mu \mathrm{M}$ concentration of each primer, $3 \mathrm{mM}$ of $\mathrm{MgCl}_{2}, 0.06 \mathrm{U}$ of Taq DNA polymerase (Thermo Fisher Scientific, Waltham, MA, USA), and $2 \mu \mathrm{L}$ of genomic DNA (of concentration $50 \mathrm{ng} / \mu \mathrm{L}$ ). Cycling conditions were initial denaturation at $95^{\circ} \mathrm{C}$ for $3 \mathrm{~min}$., then 30 cycles of $95^{\circ} \mathrm{C}$ for $30 \mathrm{~s}, 58{ }^{\circ} \mathrm{C}$ for $30 \mathrm{~s}$ and $72{ }^{\circ} \mathrm{C}$ for $90 \mathrm{~s}$, followed by a final extension at $72{ }^{\circ} \mathrm{C}$ for $10 \mathrm{~min}$. The formation of a correct PCR amplicon (1334 bp length) was checked by electrophoresis in $1 \%$ agarose gel after 1 hour at $90 \mathrm{~V}$. Three microliters of the PCR mixture were treated with $5 \mathrm{U}$ of Exonuclease I and 1.2 U of Shrimp Alkaline Phosphatase. The mixture was incubated at $37^{\circ} \mathrm{C}$ for 1 hour, and the enzymes were inactivated by incubation at $85^{\circ} \mathrm{C}$ for $15 \mathrm{~min}$.

\subsubsection{Single-Base Extension (SBE) Reaction}

Five microliters of the single-base extension (SBE) reaction mixture contained $0.5 \mu \mathrm{L}$ of the SNaPshot Multiplex Ready Reaction Mix (ABI PRISM ${ }^{\circledR}$ SNaPshot $^{\mathrm{TM}}$ Multiplex kit, Applied Biosystems, Foster City, CA, USA), $2 \mu \mathrm{L}$ of the PCR mixture after enzymatic treatment, and $1 \mu \mathrm{L}$ of the SBE primer mix (concentrations of individual primers are listed in Table 2). Five microliters of positive and negative control reactions were prepared by mixing an appropriate volume of water, $0.5 \mu \mathrm{L}$ of the SNaPshot Multiplex Ready Reaction Mix, and $0.5 \mu \mathrm{L}$ of the SNaPshot Multiplex Control Primer Mix with and without $1 \mu \mathrm{L}$ of the SNaPshot Multiplex Control Template, respectively. The SBE primer mix control reaction was prepared by mixing $3.5 \mu \mathrm{L}$ of water and $0.5 \mu \mathrm{L}$ of the $\mathrm{SNaPshot}$ Multiplex Ready Reaction Mix with $1 \mu \mathrm{L}$ of the SBE primer mix without any template. Cycling conditions were 30 cycles at $96^{\circ} \mathrm{C}$ for $10 \mathrm{~s}, 50^{\circ} \mathrm{C}$ for $5 \mathrm{~s}$, and $60^{\circ} \mathrm{C}$ for $30 \mathrm{~s}$. The SBE reaction mixture was treated with $1 \mathrm{U}$ of Shrimp Alkaline Phosphatase and incubated at $37^{\circ} \mathrm{C}$ for $1 \mathrm{~h}$, which was followed by enzyme inactivation at $85^{\circ} \mathrm{C}$ for $15 \mathrm{~min}$.

\subsubsection{Capillary Electrophoresis}

Zero point five microliters of the treated single-base extension (SBE) reaction mixture were mixed with $9.4 \mu \mathrm{L}$ of Super-DI Formamide v2 and $0.1 \mu \mathrm{L}$ of GeneScan ${ }^{\mathrm{TM}} 120 \mathrm{LIZ}^{\mathrm{TM}}$ size standard (Applied Biosystems, Foster City, CA, USA). The mixture was denatured at $95{ }^{\circ} \mathrm{C}$ for $5 \mathrm{~min}$, immediately chilled at $-20{ }^{\circ} \mathrm{C}$ for $3 \mathrm{~min}$, centrifuged and kept at $4{ }^{\circ} \mathrm{C}$. The capillary electrophoresis was performed on an automated sequencer ABI 3130-Avant Genetic Analyzer (Applied Biosystems, Foster City, CA, USA) with a $22 \mathrm{~cm}$ long capillary (Applied Biosystems, Foster City, CA, USA) filled with NimaPOP-4 (NimaGen, Nijmegen, The Netherlands). The injection at $1.0 \mathrm{kV}$ lasted $10 \mathrm{~s}$. The electrophoresis was performed at $15 \mathrm{~V}, 60^{\circ} \mathrm{C}$, and $5 \mu \mathrm{A}$ for $360 \mathrm{~s}$. The laser was set at a constant power of $15 \mathrm{~mW}$. Data were collected by the Data Collection software (version 3.0, Applied Biosystems, Foster City, CA, USA) and the results were analyzed using the GeneMapper ID software (version 3.2, Applied Biosystems, Foster City, CA, USA).

\subsection{Sanger Sequencing}

Eighty-three samples randomly chosen from the pool were sequenced using a Big Dye $^{\mathrm{TM}}$ Terminator v3.1 Cycle Sequencing kit (Applied Biosystems, Foster City, CA, USA). PCR products treated with Exonuclease I and Shrimp Alkaline Phosphatase were used as templates, and an ethanol/EDTA precipitation procedure was used for purification of sequencing reactions. The capillary electrophoresis was performed on an automated sequencer ABI 3130-Avant Genetic Analyzer with a $36 \mathrm{~cm}$ long capillary filled with NimaPOP7 (NimaGen, Nijmegen, The Netherlands). Data were collected by the Data Collection program and results were analyzed using the Sequencing Analysis program (version 5.4, Applied Biosystems, Foster City, CA, USA). 


\subsection{Calculation of Haplogenotype Combinations}

An algorithm for calculating haplogenotype combinations (Haplogenotype Calculator) from determined genotypes was developed. Combinations from 2 to 10 single nucleotide polymorphisms (SNPs) were calculated. When individual boxes (Homozygote 1, Heterozygote, Homozygote 2) were filled with particular genotypes, the program created all possible combinations of these genotypes (background data set) and each combination in the background data set had a unique number. During the next step, the program compared the genotype combination of the real sample (determined experimentally) with the background data set. When a match was found, the unique number of the corresponding genotype combination was entered into the output datasheet. The whole sample set was analyzed this way. When 4 SNPs are investigated, for example, 11 possible combinations are calculated (such as SNP1+SNP2, SNP1+SNP3, SNP1+SNP4, SNP2+SNP3, SNP2+SNP4, SNP3+SNP4; SNP1+SNP2+SNP3, SNP1+SNP2+SNP4, SNP1+SNP3+SNP4, SNP2+SNP3+SNP4; SNP1+SNP2+SNP3+SNP4). When 10 SNPs are calculated, the application generates all allowed combinations of 2-10 SNPs. This algorithm has been made freely available as an online application on the URL http:/ / 78.128.251.116/ (accessed on 2 November 2020). The website is hosted by MetaCentrum VO (https:/ / metavo.metacentrum.cz/ (accessed on 2 November 2020)). First, the spreadsheet containing the specific diagram must be downloaded from the main page of the website (link "scheme"). Then, an XML (Extensible Markup Language) file must be generated from this spreadsheet containing sample IDs and experimentally determined genotypes of SNPs. The XML file is uploaded to the application, the number of SNPs is selected, individual fields are filled with the allele combination for each SNP, and the calculation is run. The output datasheet is saved as an *.xlsx file. According to the number of analyzed SNPs, the output file contains separated sheets with combinations of SNP pairs, SNP triplets, SNP quadruplets etc. The calculation time depends on the number of SNPs and especially on the number of analyzed samples in the sample pool; it can take up to 1 hour. A step-by-step manual on the use of this application for calculating haplogenotypes is available on the main page of the website.

\subsection{Statistical Analysis}

Hardy-Weinberg equilibrium, linkage disequilibrium, minor allele frequencies and haplotype frequencies were calculated in the Haploview software (version 4.2, Broad Institute, Cambridge, MA, USA) [19].

\section{Results}

\subsection{Design and Optimization of the SNaPshot Assay}

The SNaPshot assay was developed and optimized for simultaneous detection of six single nucleotide polymorphisms (SNPs) in the MBL2 gene. PCR was designed to amplify a single amplicon carrying all SNPs of interest. The PCR was optimized by adjusting the concentrations of the primers $(0.3-0.5 \mu \mathrm{M})$ and $\mathrm{MgCl}_{2}(1-6 \mathrm{mM})$ and the cycling conditions (gradient of $\mathrm{T}_{\mathrm{a}} 54-62{ }^{\circ} \mathrm{C}$, with a 3-5 min. duration of initial denaturation, for $25-45$ cycles). To minimize reaction costs, the volume of the SNaPshot Multiplex Ready Reaction Mix added to the single-base extension (SBE) reaction was reduced, as well as the total volumes of the SBE and PCR reactions. Considering the positions of three polymorphisms in the exon 1, which are very close to each other, two out of six specific primers used in the SBE reaction were synthesized with degenerate bases incorporated into their sequence (Table 2).

Six singleplex SBE reactions were performed with a PCR template to determine the position of the peaks of individual SNP alleles in the electropherogram and to check for peaks caused by non-specific annealing. A multiplex SBE reaction with the SBE primer mix, and without the PCR template, served to check for the formation of heterodimer products. Overlapping of the peaks of the three shortest SBE primers was observed after analysis of the multiplex SBE reaction; nevertheless, it was still possible to determine genotypes due to the color difference of incorporated bases belonging to the particular SNPs (Figure 1). 
Concentrations of specific primers were adjusted, and the number of SBE reaction cycles was increased to obtain more balanced peak heights.
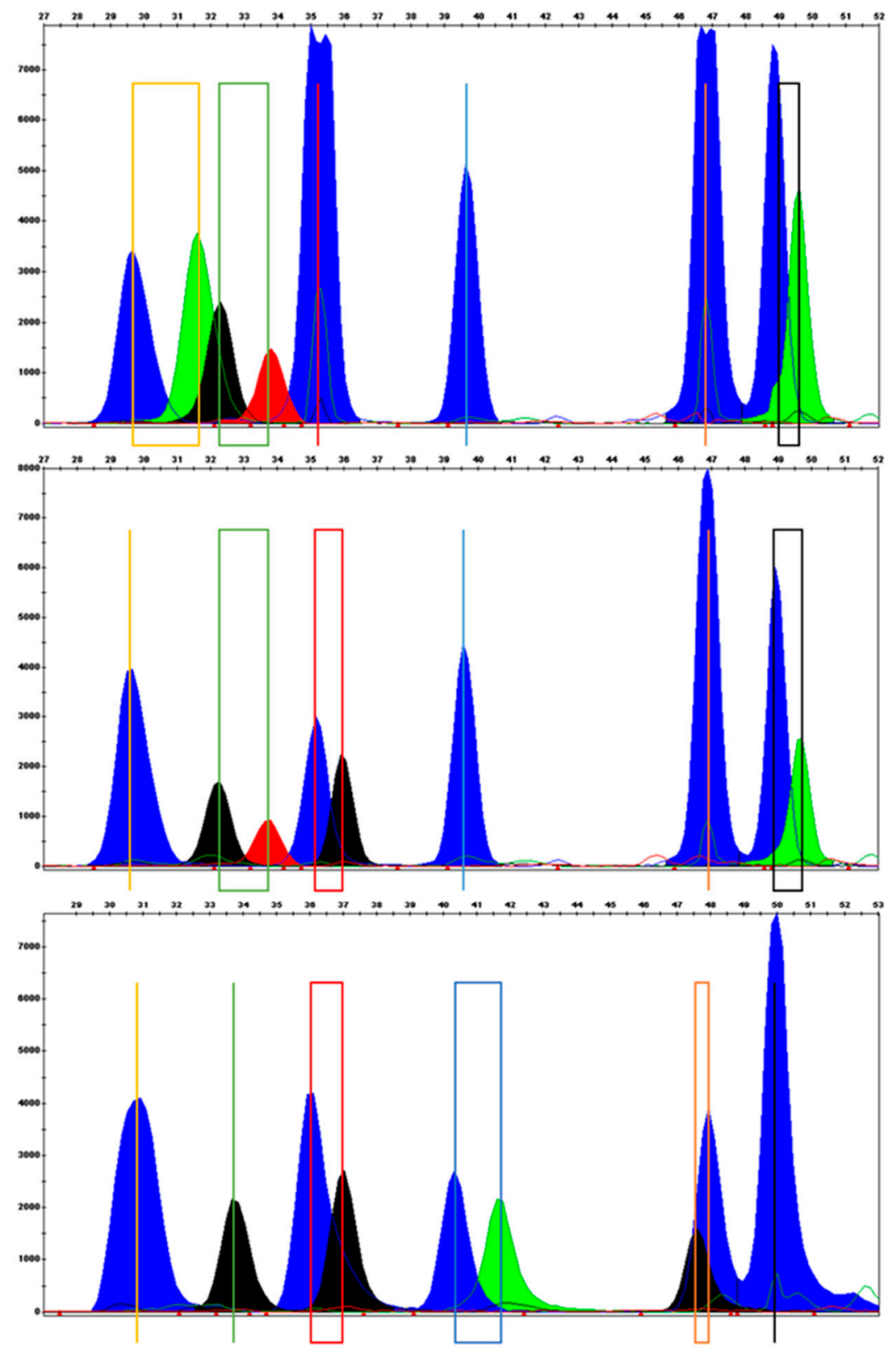

Figure 1. Electropherograms of three samples showing peaks of all alleles. Alleles of individual single nucleotide polymorphisms (SNPs) are highlighted by color line or rectangle (yellow-allele $\mathrm{A} / \mathrm{B}$, green-allele $\mathrm{A} / \mathrm{C}$, red-allele $\mathrm{X} / \mathrm{Y}$, blue-allele $\mathrm{A} / \mathrm{D}$, orange-allele $\mathrm{H} / \mathrm{L}$, black-allele $\mathrm{P} / \mathrm{Q}$ ).

Finally, the panel and bins for allele identification were entered into the GeneMapper program to enable the automatic analysis.

\subsection{Mannose-Binding Lectin Gene (MBL2) Genotyping}

Altogether, 328 samples were successfully genotyped by the SNaPshot assay. Frequencies of the variant alleles of all six MBL2 gene single nucleotide polymorphisms (SNPs) (rs1800451, rs1800450, rs5030737, rs7095891, rs7096206, rs11003125) were in accordance with the Hardy-Weinberg equilibrium ( $p=1.00,0.73,0.80,0.12,0.38,0.74$, respectively). The pairwise linkage disequilibrium (LD) was calculated, and all studied MBL2 SNPs were in the LD block (Supplementary Figure S1). Minor allele frequencies (MAFs) in the Czech 
population corresponded to MAFs from the 1000 Genomes Project Phase 3 (NCBI database dbSNP) for the European population. MAFs of all studied MBL2 SNPs in other populations also have been included in Table 3 for comparison. Calculated haplotype frequencies were similar to those reported in the Danish population (Table 4).

Table 3. Minor allele frequencies (MAFs) of mannose-binding lectin gene (MBL2) single nucleotide polymorphisms (SNPs) in a genotyped sample pool of Czech healthy individuals and in European (EUR), African (AFR), East Asian (EAS), South Asian (SAS) and American (AMR) populations according to NCBI database dbSNP (https: / www.ncbi.nlm.nih.gov/snp / (accessed on 2 November 2020)).

\begin{tabular}{cccccccc}
\hline & & \multicolumn{7}{c}{ MAF (\%) } \\
\cline { 3 - 8 } rs Number & Allele & $\begin{array}{c}\boldsymbol{n}=\mathbf{3 2 8} \\
\text { Czech }\end{array}$ & $\begin{array}{c}\boldsymbol{n = 1 0 0 6} \\
\text { EUR }\end{array}$ & $\begin{array}{c}n=\mathbf{1 3 2 2} \\
\text { AFR }\end{array}$ & $\begin{array}{c}n=\mathbf{1 0 0 8} \\
\text { EAS }\end{array}$ & $\begin{array}{c}n=\mathbf{9 7 8} \\
\text { SAS }\end{array}$ & $\begin{array}{c}n=\mathbf{6 9 4} \\
\text { AMR }\end{array}$ \\
\hline rs11003125 & $\mathrm{H}$ & 38.3 & 38.6 & 8.7 & 44.6 & 31.0 & 40.0 \\
rs7096206 & $\mathrm{X}$ & 21.4 & 22.1 & 15.4 & 18.6 & 28.0 & 13.0 \\
rs7095891 & $\mathrm{Q}$ & 23.6 & 19.8 & 54.0 & 13.8 & 25.0 & 17.0 \\
rs5030737 & $\mathrm{D}$ & 8.5 & 6.0 & 0.2 & 0.1 & 5.0 & 3.0 \\
rs1800450 & $\mathrm{B}$ & 13.5 & 14.1 & 1.4 & 14.8 & 15.0 & 22.0 \\
rs1800451 & $\mathrm{C}$ & 1.8 & 1.2 & 25.9 & 0.0 & 4.0 & 2.0 \\
\hline
\end{tabular}

$n$, number of subjects.

Table 4. Mannose-binding lectin gene (MBL2) haplotype frequencies in a genotyped sample pool of 328 Czech and 100 Danish healthy individuals.

\begin{tabular}{ccccc}
\hline $\begin{array}{c}\text { MBL2 } \\
\text { Haplotype }\end{array}$ & $\begin{array}{c}\text { Combination } \\
\text { of Alleles } \\
\text { (Secretor } \\
\text { Haplotype) }\end{array}$ & MBL Phenotype $\mathbf{2}^{2}$ & $\begin{array}{c}\text { Frequency in } \\
\text { Czech } \\
\text { Population } \\
\text { (\%) }\end{array}$ & $\begin{array}{c}\text { Frequency in } \\
\text { Danish } \\
\text { Population }\end{array}$ \\
\hline G G C G G & HYPA & High & 29.8 & 28.5 \\
C T C G G & LYQA & High & 21.7 & 23.5 \\
C C C G G & LXPA & Low & 21.4 & 19.5 \\
C G C A G & LYPB & Undetectable & 13.3 & 13.5 \\
G G T G G & HYPD & Undetectable & 8.5 & 8.5 \\
C G C G G & LYPA & Intermediate & 3.3 & 4.5 \\
C G C G A & LYQC & Undetectable & 1.8 & 2.0 \\
C G T A G & LYQB & Undetectable & 0.2 & - \\
\hline
\end{tabular}

${ }^{1}$ rs11003125, rs7096206, rs7095891, rs5030737, rs1800450, rs1800451; ${ }^{2}$ According to Cedzyński et al. and Verdu et al. $[4,11] ;^{3}$ According to Steffensen et al. [20].

\subsection{Validation of the SNaPshot Assay Results}

To validate results obtained by the developed SNaPshot assay, we used classical Sanger sequencing of 83 randomly selected samples. A perfect match (100\% fit) was found between genotypes determined by Sanger sequencing and the SNaPshot assay.

\subsection{Calculation of Haplogenotype Combinations}

The Haplogenotype Calculator created within the scope of this study was used for calculation of haplogenotype combinations from six single nucleotide polymorphisms (SNPs) in the MBL2 gene determined in 328 samples. Distribution of the MBL2 haplogenotypes calculated from all six SNPs among samples from healthy individuals is listed in Table 5. 
Table 5. Mannose-binding lectin gene (MBL2) haplogenotype distribution among samples from 328 healthy Czech individuals.

\begin{tabular}{|c|c|c|}
\hline MBL2 Haplogenotype ${ }^{1}$ & $\begin{array}{c}\text { Combination of Secretor } \\
\text { Haplotypes }\end{array}$ & Frequency $(\%)$ \\
\hline GC GG CT CC GG GG & HYPA/LYQA & 16.2 \\
\hline GC GC CC CC GG GG & HYPA/LXPA & 11.9 \\
\hline CC GC CT CC GG GG & LYQA/LXPA & 10.1 \\
\hline GG GG CC CC GG GG & HYPA/HYPA & 7.9 \\
\hline GC GG CC CC GA GG & HYPA/LYPB & 7.3 \\
\hline CC GG CT CC GA GG & LYQA/LYPB & 6.1 \\
\hline CC CC CC CC GG GG & LXPA/LXPA & 5.5 \\
\hline GG GG CC CT GG GG & HYPA/HYPD & 5.2 \\
\hline CC GC CC CC GA GG & LXPA/LYPB & 4.0 \\
\hline CC GG TT CC GG GG & LYQA/LYQA & 3.7 \\
\hline GC GG CC CT GA GG & LYPB/HYPD & 3.0 \\
\hline GC GC CC CT GG GG & LXPA/HYPD & 3.0 \\
\hline GC GG CT CT GG GG & LYQA/HYPD & 2.4 \\
\hline GC GG CC CC GG GG & HYPA/LYPA & 2.4 \\
\hline CC GG CC CC AA GG & $\mathrm{LYPB} / \mathrm{LYPB}$ & 2.1 \\
\hline CC GC CT CC GG GA & LXPA/LYQC & 1.8 \\
\hline CC GG CC CC GA GG & LYPB/LYPA & 1.2 \\
\hline CC GG CT CC GG GG & LYQA/LYPA & 1.2 \\
\hline GC GG CC CT GG GG & HYPD/LYPA & 0.9 \\
\hline CC GC CC CC GG GG & LXPA/LYPA & 0.9 \\
\hline GG GG CC TT GG GG & HYPD/HYPD & 0.9 \\
\hline GC GG CT CC GG GA & HYPA/LYQC & 0.6 \\
\hline CC GG CT CC GA GA & LYPB/LYQC & 0.6 \\
\hline CC GG TT CC GG GA & LYQA/LYQC & 0.3 \\
\hline GC GG CT CT GG GA & HYPD/LYQC & 0.3 \\
\hline GC GG CT CC GA GG & HYPA/LYQB & 0.3 \\
\hline
\end{tabular}

${ }^{1}$ rs11003125, rs7096206, rs7095891, rs5030737, rs1800450, rs1800451; ${ }^{2}$ Translated from the haplogenotypes.

\section{Discussion}

Here, the SNaPshot assay was introduced for simultaneous genotyping of the six functional polymorphisms within the MBL2 gene. Similar assays have recently been used but none of these was designed for genotyping all six single nucleotide polymorphisms (SNPs) [21-24]. Due to the proximity of the individual analyzed SNPs, we performed a singleplex PCR reaction, which subsequently served as a template for the single-base extension (SBE) reaction. We have achieved consistent results within the optimized SBE reaction, even with a significantly minimized volume $(0.5 \mu \mathrm{L})$ of the commercially used mix. Regarding a small portion of analyzed samples $(4.9 \%)$, non-specific peaks in electropherograms were observed. These peaks were at the same positions and colors as peaks of alleles $\mathrm{D}$ and $\mathrm{Q}$, which could be potentially problematic during the consequent analysis. However, we eliminated the risk of inaccurate allele identification by setting the heterozygote balance (the min peak height ratio) in the GeneMapper software. All the problematic samples were stored at $+4{ }^{\circ} \mathrm{C}$ after DNA isolation for more than six months, or their stock solutions were stored at $-20^{\circ} \mathrm{C}$ for more than two years. Thus, it is very likely that these samples contained partially degraded DNA, which could adversely affect the SNaPshot assay effectiveness with potential amplification bias.

The choice of an appropriate method for genotyping SNPs in clinical or research laboratories depends on several factors, including the number and type of samples and the available quantity / quality of the analyzed DNA. Also, financial, material, and instrumentation requirements, or the availability of a commercial genotyping service, are considered. During MBL2 genotyping, the proximity of the polymorphisms in the MBL2 exon 1 is a crucial factor that must be taken into account in selecting the method. A combination of 
methods suitable for determining SNPs in the promoter and the first exon often needs to be applied in MBL2 genotyping [25,26].

Up to this day, a wide spectrum of other methods have been used for detection of MBL2 gene variants, including commercially available TaqMan assays [27], high-resolution melt analysis (HRMA) [28], reverse hybridization with membrane-immobilized sequencespecific oligonucleotide probes (reverse PCR-SSOP) [29], PCR with sequence-specific primers (SSP-PCR) [30,31], PCR and restriction-fragment length polymorphism (PCRRFLP) analysis [32], an oligonucleotide ligation assay [33,34], a single-strand conformation polymorphism technique (PCR-SSCP) [35], the iPLEX assay on a MassArray system [36], Sanger sequencing [37], and pyrosequencing [38].

Genotyping methods based on PCR or enzymatic digestion of specific PCR products with analysis of genotypes on agarose/acrylamide gel are widely used due to their simplicity and low requirement for materials and instrumentation. Conversely, these techniques are laborious and, in effect, not suitable for high-throughput genotyping. Furthermore, the low sensitivity and robustness of these methods might pose a problem. A TaqMan assay, which belongs to high-throughput methods, is quite simple, fast, and sensitive. However, analyses of interrogated polymorphisms are performed in separate reactions, leading to a higher consumption of the template DNA. The assay can be multiplexed but, in view of the proximity of the individual SNPs in exon 1 of MBL2 it can be very difficult, if not impossible. This could lead to the need for several individual reactions, which would render the analysis expensive.

Conversely, the proximity of SNPs in exon 1 become an advantage when the pyrosequencing method is used for the genotyping of these SNPs. Pyrosequencing and HRMA are very rapid and sensitive methods; however, four (pyrosequencing) and five (HRMA) analyses, respectively, are needed to determine six MBL2 polymorphisms, which increases the consumption of the template DNA.

Unlike these methods, the SNaPshot minisequencing method is at present the only method capable of reliable automated determination of the complete MBL2 haplogenotype in a single analysis and is less prone to heterozygosity loss than Sanger sequencing [39]. The high sensitivity and short analysis time also count among the benefits of this method [40]. The comparison of methods used for MBL2 genotyping is summarized in Table 6.

During our study, 328 samples from healthy individuals from the Czech population were genotyped using the SNaPshot assay. Minor allele frequencies (MAFs) of all six MBL2 SNPs in the healthy Czech population were similar to the MAFs deposited in the database for the European population (Table 3). The calculated haplotype frequencies were consistent with those determined in the Danish [20] and Czech [42] populations (Table 4). A rare secretor haplotype LYQB was detected in the sample pool. To our knowledge, it is the first evidence of this haplotype in the Czech population. Additionally, MBL2 haplogenotypes from six SNPs were determined in the Czech population for the first time (Table 5).

Concerning some cases, diseases can be associated with haplotypes (i.e., with the sequential allele arrangement of particular SNPs) or diplotypes (pairs of haplotypes) rather than alleles or genotypes alone [47]. Furthermore, the frequency of alleles can be in a strong Hardy-Weinberg Disequilibrium in sample sets of subjects with investigated diseases. Regarding such instances, diplotype-based association analyses are more powerful than haplotype-based analyses [48]. Methods used for genotyping are unable to determine haplotypes, although methods capable of identifying diplotypes have been developed [49]. Therefore, several programs for haplotype phasing (haplotype estimation from determined genotypes) [50,51], calculation of haplotype frequencies and association tests $[52,53]$, and diplotype-based association analysis [54] have been developed. 
Table 6. Comparison of methods used for mannose-binding lectin gene (MBL2) genotyping.

\begin{tabular}{|c|c|c|c|c|c|c|c|c|c|}
\hline & $\begin{array}{c}\text { Allele } \\
\text {-Specific PCR } \\
\text { (AS-PCR) }\end{array}$ & $\begin{array}{c}\text { ARMS } \\
\text { 3/Double } \\
\text { ARMS }{ }^{3} \\
(+ \\
\text { Multiplex } \\
\text { Allele } \\
\text {-Specific PCR) }\end{array}$ & $\begin{array}{l}\text { PCR and } \\
\text { Restriction- } \\
\text { Fragment } \\
\text { Length } \\
\text { Polymorphism } \\
\text { (PCR-RFLP) }\end{array}$ & $\begin{array}{l}\text { Commercial } \\
\text { TaqMan } \\
\text { Assay }^{5}\end{array}$ & $\begin{array}{c}\text { High- } \\
\text { Resolution } \\
\text { Melt } \\
\text { Analysis } \\
\text { (HRMA) }\end{array}$ & $\begin{array}{c}\text { Commercial } \\
\text { INNO-LiPA } \\
\text { MBL2 kit } \\
\text { (Reverse } \\
\text { PCR-SSOP) }\end{array}$ & $\begin{array}{c}\text { Pyro- } \\
\text { Sequencing }\end{array}$ & $\begin{array}{c}\text { Sanger } \\
\text { Sequencing }\end{array}$ & $\begin{array}{c}\text { MBL2 } \\
\text { SNaPshot } \\
\text { Assay }\end{array}$ \\
\hline $\begin{array}{c}\text { principle of allele } \\
\text { discrimina- } \\
\text { tion/detection }\end{array}$ & $\begin{array}{l}\text { PCR with a } \\
\text { primer specific } \\
\text { for one allele }\end{array}$ & $\begin{array}{l}\text { PCR with } \\
\text { primers specific } \\
\text { for both alleles }\end{array}$ & $\begin{array}{l}\text { allele-specific } \\
\text { enzymatic } \\
\text { cleavage of PCR } \\
\text { amplicon }\end{array}$ & $\begin{array}{c}\text { allele-specific } \\
\text { hybridization of } \\
\text { fluorescently } \\
\text { labelled probe }\end{array}$ & $\begin{array}{l}\text { temperature- } \\
\text { dependent } \\
\text { allele- } \\
\text { specific } \\
\text { hybridiza- } \\
\text { tion of } \\
\text { fluores- } \\
\text { cently } \\
\text { labelled } \\
\text { probe }\end{array}$ & $\begin{array}{l}\text { hybridization of } \\
\text { biotinylated } \\
\text { PCR product } \\
\text { with membrane } \\
\text { immobilized } \\
\text { sequence- } \\
\text { specific } \\
\text { oligonucleotide } \\
\text { probes }\end{array}$ & $\begin{array}{l}\text { chemiluminiscence- } \\
\text { based detection of } \\
\text { nucleotides during } \\
\text { sequencing-by- } \\
\text { synthesis } \\
\text { reaction }\end{array}$ & $\begin{array}{l}\text { detection of the } \\
\text { sequence of an } \\
\text { oligonucleotide } \\
\text { amplified in } \\
\text { PCR with } \\
\text { fluorescently } \\
\text { labelled } \\
\text { dideoxyribonu- } \\
\text { cleotides }\end{array}$ & $\begin{array}{c}\text { allele- } \\
\text { specific SBE } \\
\text { by a single } \\
\text { fluores- } \\
\text { cently } \\
\text { labelled } \\
\text { dideoxyri- } \\
\text { bonu- } \\
\text { cleotide } \\
\text { (minise- } \\
\text { quencing) }\end{array}$ \\
\hline post-PCR analysis & yes & yes & yes & no & $\begin{array}{l}\text { no, when } \\
\text { real-time } \\
\text { PCR thermo- } \\
\text { cycler } \\
\text { is used }\end{array}$ & yes & no & yes & yes \\
\hline analysis time & $2 h^{2}$ & $2-3 h^{2}$ & $\begin{array}{c}2 \mathrm{~h} \\
+ \\
1-3 \mathrm{~h}^{4}\end{array}$ & $1-2 \mathrm{~h}^{6}$ & $\begin{array}{c}1-1.5 \mathrm{~h} \\
+ \\
2-8 \text { min. }^{8}\end{array}$ & $3-4 \mathrm{~h}$ & $2-3 \mathrm{~h}$ & $6-7 \mathrm{~h}$ & $5-6 \mathrm{~h}$ \\
\hline
\end{tabular}


Table 6. Cont.

\begin{tabular}{|c|c|c|c|c|c|c|c|c|c|}
\hline & $\begin{array}{c}\text { Allele } \\
\text {-Specific PCR } \\
\text { (AS-PCR) }\end{array}$ & $\begin{array}{c}\text { ARMS } \\
\text { 3/Double }^{3 / \text { Dous }}{ }^{3} \\
\text { ARMS }^{2} \\
(+ \\
\text { Multiplex } \\
\text { Allele } \\
\text {-Specific PCR) }\end{array}$ & $\begin{array}{l}\text { PCR and } \\
\text { Restriction- } \\
\text { Fragment } \\
\text { Length } \\
\text { Polymorphism } \\
\text { (PCR-RFLP) }\end{array}$ & $\begin{array}{l}\text { Commercial } \\
\text { TaqMan } \\
\text { Assay }^{5}\end{array}$ & $\begin{array}{c}\text { High- } \\
\text { Resolution } \\
\text { Melt } \\
\text { Analysis } \\
\text { (HRMA) }\end{array}$ & $\begin{array}{c}\text { Commercial } \\
\text { INNO-LiPA } \\
\text { MBL2 kit } \\
\text { (Reverse } \\
\text { PCR-SSOP) }\end{array}$ & $\begin{array}{c}\text { Pyro- } \\
\text { Sequencing }\end{array}$ & $\begin{array}{c}\text { Sanger } \\
\text { Sequencing }\end{array}$ & $\begin{array}{c}\text { MBL2 } \\
\text { SNaPshot } \\
\text { Assay }\end{array}$ \\
\hline $\begin{array}{c}\text { number of work } \\
\text { steps }\end{array}$ & $\begin{array}{c}2 \\
\text { (PCR, gel } \\
\text { analysis) }\end{array}$ & $\begin{array}{c}2 \\
\text { (PCR, gel } \\
\text { analysis) }\end{array}$ & $\begin{array}{c}4 \\
\text { (PCR, gel } \\
\text { analysis, RFLP, } \\
\text { gel analysis) }\end{array}$ & $\begin{array}{c}1 \\
\text { (real-time PCR) }\end{array}$ & $\begin{array}{c}1 \\
\text { (when } \\
\text { real-time } \\
\text { PCR thermo- } \\
\text { cycler } \\
\text { is used for } \\
\text { PCR and } \\
\text { subsequent } \\
\text { melting } \\
\text { temperature } \\
\text { analysis) }\end{array}$ & $\begin{array}{c}9 \\
\text { (PCR, gel } \\
\text { analysis, } \\
\text { denaturation, } \\
\text { hybridization, } 2 \\
\text { washing steps, } \\
\text { 3-step color } \\
\text { development) }\end{array}$ & $\begin{array}{c}4 \\
\text { (PCR, gel analysis, } \\
\text { purification, } \\
\text { pyrosequencing) }\end{array}$ & $\begin{array}{c}5 \\
\text { (PCR, enzymatic } \\
\text { cleaning, } \\
\text { sequencing } \\
\text { reaction, } \\
\text { purification, } \\
\text { analysis on } \\
\text { sequencer) }\end{array}$ & $\begin{array}{c}5 \\
\text { (PCR, } \\
\text { enzymatic } \\
\text { cleaning, } \\
\text { SBE reaction, } \\
\text { enzymatic } \\
\text { cleaning, } \\
\text { analysis on } \\
\text { sequencer) }\end{array}$ \\
\hline automatic analysis & no & no & no & yes & yes & no & yes & yes & yes \\
\hline $\begin{array}{c}\text { number of } \\
\text { analyses for } \\
\text { complete } M B L 2 \\
\text { haplogenotype } 1\end{array}$ & 12 & 6 & 6 & 6 & 5 & 1 & $4^{9}$ & 2 & 1 \\
\hline $\begin{array}{c}\text { number of } \\
\text { oligonucleotide } \\
\text { primers + labelled } \\
\text { primers/probes } \\
\text { for complete } M B L 2 \\
\text { haplogenotype }^{1}\end{array}$ & 24 primers & 15 primers & 6 primers & $\begin{array}{c}6 \text { TaqMan } \\
\text { assays }(12 \\
\text { primers }+12 \\
\text { TaqMan probes) }\end{array}$ & $\begin{array}{c}10 \text { primers + } \\
5 \text { TaqMan } \\
\text { probes }\end{array}$ & 4 primers & $\begin{array}{c}8 \text { primers }+4 \\
\text { biotinylated } \\
\text { primers }\end{array}$ & 2 primers & 8 primers \\
\hline $\begin{array}{l}\text { estimated cost of } \\
\text { analysis of whole } \\
\text { haplogenotype }\end{array}$ & $1 \mathrm{USD}$ & 1 USD & 2 USD & 2 USD & 1 USD & $\begin{array}{l}\text { product was } \\
\text { discontinued }\end{array}$ & 2 USD & 5 USD & 1.50 USD \\
\hline $\begin{array}{c}\text { input amount } \\
\text { of template DNA }\end{array}$ & $20-200 \mathrm{ng}$ & 20-200 ng & $50-500 \mathrm{ng}$ & $1-20 \mathrm{ng}$ & 10-20 ng & $200-500 \mathrm{ng}$ & $10-100 \mathrm{ng}$ & $10-250 \mathrm{ng}$ & $10-100 \mathrm{ng}$ \\
\hline
\end{tabular}


Table 6. Cont.

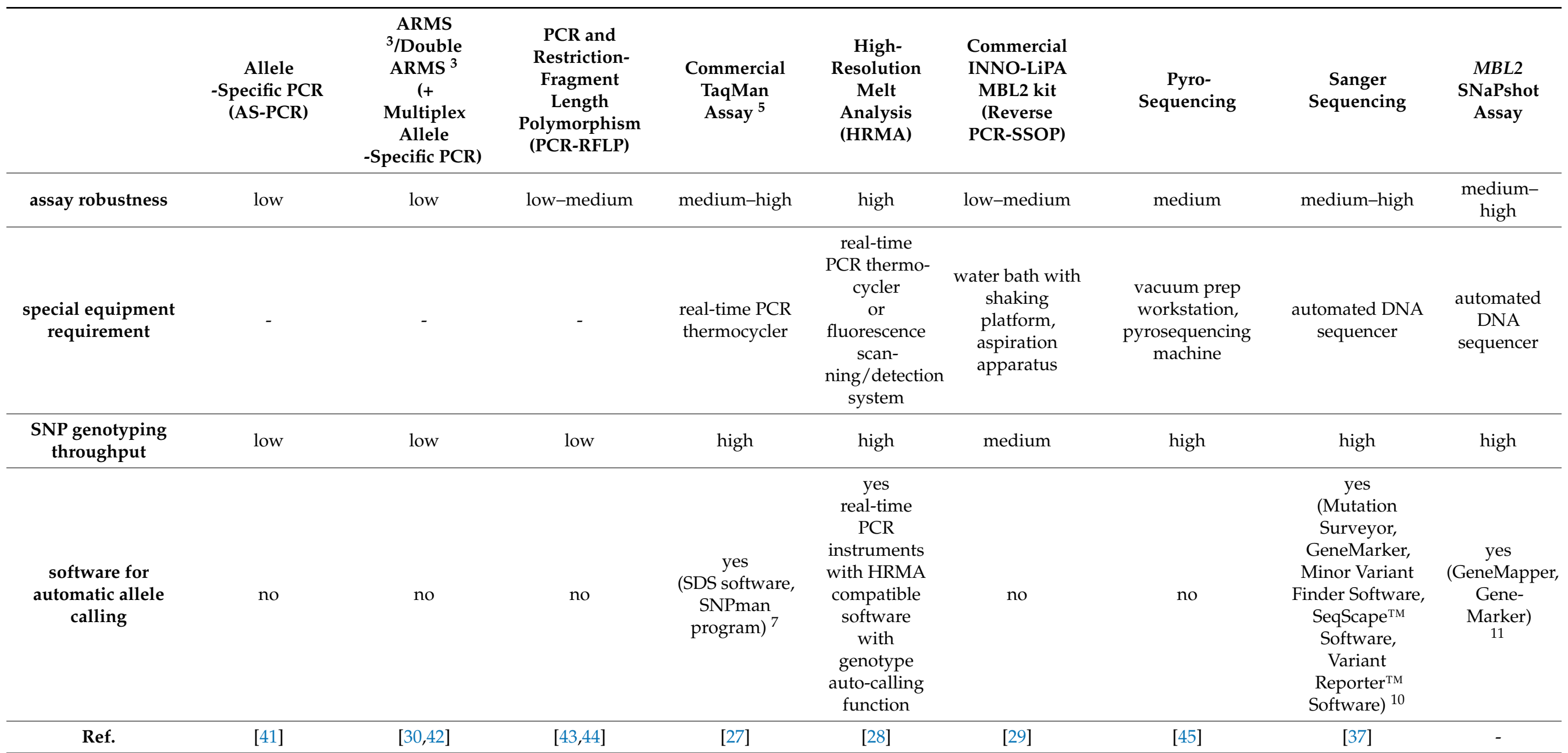

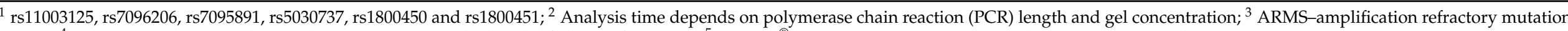

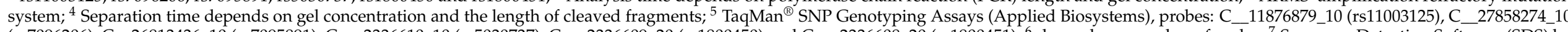

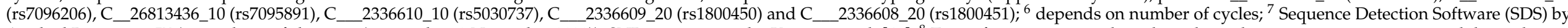

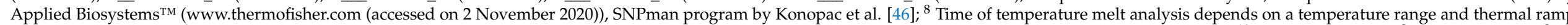

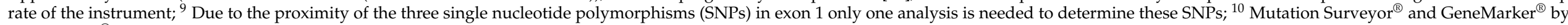

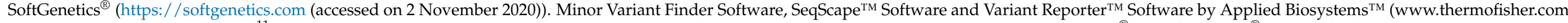

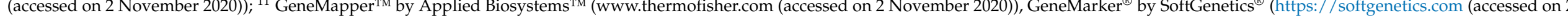
November 2020)). Single-base extension (SBE). Mannose-binding lectin gene (MBL2). Reverse hybridization with membrane-immobilized sequence-specific oligonucleotide probes (reverse PCR-SSOP). 
Conversely, haplogenotypes (combinations of unphased genotypes) have been used in association studies [55]. Here, a simple online application for the calculation of haplogenotypes by combining determined genotypes of two to ten SNPs has been prepared to facilitate further statistical analyses.

\section{Conclusions}

A novel SNaPshot assay for detection of six single nucleotide polymorphisms (SNPs) in the MBL2 gene was developed, optimized, and used for the genotyping of 328 samples from healthy individuals from the Czech population. Results of the assay were validated through comparison with results of sequencing analysis, which were concordant. Calculated minor allele frequencies (MAFs) were in accordance with MAFs for the European population deposited in the database. This high-throughput, cost-effective, and accurate method, therefore, can be used in further association studies as well as in clinical practice. The main limitation of the method is the quality of the DNA in tested samples. Moreover, the freely available online application developed for this study can be employed for the calculation of haplogenotype combinations from up to 10 genotypes.

Supplementary Materials: The following are available online at https: / / www.mdpi.com/2075-441 8/11/2/301/s1, Figure S1: Linkage disequilibrium (LD) maps for 6 single nucleotide polymorphisms in the mannose-binding lectin gene (MBL2).

Author Contributions: J.M. and J.L. are responsible for the methodology, validation, formal analysis, investigation, data curation and visualization. P.S. programmed the algorithm and managed the online application. J.M. prepared the original draft. J.L., L.I.H., Z.D. and P.B.L. reviewed and edited the manuscript. P.B.L. is responsible for the conceptualization, methodology, validation, formal analysis, investigation, data curation and visualization. All authors have read and agreed to the published version of the manuscript.

Funding: The study was supported by the Ministry of Health of the Czech Republic, grants No. NU20-08-00205 and NV17-30439A, the project MUNI/A/1428/2019, and funds from the Faculty of Medicine MU to a junior researcher (Zdenek Danek, ROZV/28/LF4/20). All rights reserved.

Institutional Review Board Statement: The study was conducted according to the guidelines of the Declaration of Helsinki, and approved by the Committee for Ethics of the Faculty of Medicine, Masaryk University Brno, and St. Anne's Faculty Hospital (1G/2017, 24 June 2016).

Informed Consent Statement: Informed consent was obtained from all subjects involved in the study.

Acknowledgments: Computational resources were provided by the CESNET LM2015042 and the CERIT Scientific Cloud LM2015085, provided under the program "Projects of Large Research, Development, and Innovations Infrastructures".

Conflicts of Interest: The authors declare no conflict of interest. The funders had no role in the design of the study; in the collection, analyses, or interpretation of data; in the writing of the manuscript, or in the decision to publish the results.

\section{References}

1. Dommett, R.M.; Klein, N.; Turner, M.W. Mannose-Binding Lectin in Innate Immunity: Past, Present and Future. Tissue Antigens 2006, 68, 193-209. [CrossRef] [PubMed]

2. Takahashi, K.; Ip, W.E.; Michelow, I.C.; Ezekowitz, R.A.B. The Mannose-Binding Lectin: A Prototypic Pattern Recognition Molecule. Curr. Opin. Immunol. 2006, 18, 16-23. [CrossRef]

3. Ip, E.W.K.; Takahashi, K.; Ezekowitz, A.R.B.; Stuart, L.M. Mannose-Binding Lectin and Innate Immunity. Immunol. Rev. 2009, 230, 9-21. [CrossRef] [PubMed]

4. Cedzyński, M.; Kilpatrick, D.C.; Świerzko, A.S. Mannose-Binding Lectin. In The Complement FactsBook; Elsevier: Amsterdam, The Netherlands, 2018; pp. 33-43. ISBN 978-0-12-810420-0.

5. dos Santos Silva, P.M.; de Oliveira, W.F.; Albuquerque, P.B.S.; dos Santos Correia, M.T.; Coelho, L.C.B.B. Insights into AntiPathogenic Activities of Mannose Lectins. Int. J. Biol. Macromol. 2019, 140, 234-244. [CrossRef] [PubMed]

6. Kjaer, T.R.; Thiel, S.; Andersen, G.R. Toward a Structure-Based Comprehension of the Lectin Pathway of Complement. Mol. Immunol. 2013, 56, 222-231. [CrossRef] 
7. $\quad$ Kjaer, T.R.; Jensen, L.; Hansen, A.; Dani, R.; Jensenius, J.C.; Dobó, J.; Gál, P.; Thiel, S. Oligomerization of Mannan-Binding Lectin Dictates Binding Properties and Complement Activation. Scand. J. Immunol. 2016, 84, 12-19. [CrossRef]

8. Garred, P.; Genster, N.; Pilely, K.; Bayarri-Olmos, R.; Rosbjerg, A.; Ma, Y.J.; Skjoedt, M.-O. A Journey through the Lectin Pathway of Complement-MBL and Beyond. Immunol. Rev. 2016, 274, 74-97. [CrossRef]

9. Dobó, J.; Kocsis, A.; Gál, P. Be on Target: Strategies of Targeting Alternative and Lectin Pathway Components in ComplementMediated Diseases. Front. Immunol. 2018, 9, 1851. [CrossRef]

10. Heitzeneder, S.; Seidel, M.; Förster-Waldl, E.; Heitger, A. Mannan-Binding Lectin Deficiency—Good News, Bad News, Doesn't Matter? Clin. Immunol. 2012, 143, 22-38. [CrossRef]

11. Verdu, P.; Barreiro, L.B.; Patin, E.; Gessain, A.; Cassar, O.; Kidd, J.R.; Kidd, K.K.; Behar, D.M.; Froment, A.; Heyer, E.; et al. Evolutionary Insights into the High Worldwide Prevalence of MBL2 Deficiency Alleles. Hum. Mol. Genet. 2006, 15, 2650-2658. [CrossRef]

12. Seyfarth, J.; Garred, P.; Madsen, H.O. The 'Involution' of Mannose-Binding Lectin. Hum. Mol. Genet. 2005, 14, 2859-2869. [CrossRef] [PubMed]

13. Bouwman, L.H.; Roep, B.O.; Roos, A. Mannose-Binding Lectin: Clinical Implications for Infection, Transplantation, and Autoimmunity. Hum. Immunol. 2006, 67, 247-256. [CrossRef]

14. Hou, J.; Ding, J.; Li, L.; Peng, Y.; Gao, X.; Guo, Z. Association of Sirtuin 1 Gene Polymorphisms with Nephrolithiasis in Eastern Chinese Population. Ren. Fail. 2019, 41, 34-41. [CrossRef]

15. Geng, Y.; Li, L.; Wang, X.; He, F.; Zhou, Y.; Yang, M.; Xu, Y. Interleukin-10 Polymorphisms Affect the Key Periodontal Pathogens in Chinese Periodontitis Patients. Sci. Rep. 2018, 8, 9068. [CrossRef]

16. Zhao, M.; Zhang, Y.; Liu, Y.; Sun, G.; Tian, H.; Hong, L. Polymorphisms in MAPK9 (Rs4147385) and CSF1R (Rs17725712) Are Associated with the Development of Inhibitors in Patients with Haemophilia A in North China. Int. J. Lab. Hematol. 2019, 41, 572-577. [CrossRef] [PubMed]

17. Sambrook, J.; Fritsch, E.; Maniatis, T. Molecular Cloning: A Laboratory Manual: Volume 2, 2nd ed.; Cold Spring Harbor: New York, NY, USA, 1989; ISBN 978-0-87969-309-1.

18. Świerzko, A.S.; Cedzyński, M. The Influence of the Lectin Pathway of Complement Activation on Infections of the Respiratory System. Front. Immunol. 2020, 11, 585243. [CrossRef]

19. Barrett, J.C.; Fry, B.; Maller, J.; Daly, M.J. Haploview: Analysis and Visualization of LD and Haplotype Maps. Bioinformatics 2005, 21, 263-265. [CrossRef] [PubMed]

20. Steffensen, R.; Thiel, S.; Varming, K.; Jersild, C.; Jensenius, J.C. Detection of Structural Gene Mutations and Promoter Polymorphisms in the Mannan-Binding Lectin (MBL) Gene by Polymerase Chain Reaction with Sequence-Specific Primers. J. Immunol. Methods 2000, 241, 33-42. [CrossRef]

21. Zhang, N.; Zhuang, M.; Ma, A.; Wang, G.; Cheng, P.; Yang, Y.; Wang, X.; Zhang, J.; Chen, X.; Lu, M. Association of Levels of Mannose-Binding Lectin and the MBL2 Gene with Type 2 Diabetes and Diabetic Nephropathy. PLoS ONE 2013, 8, e83059. [CrossRef]

22. Yarden, J.; Radojkovic, D.; De Boeck, K.; Macek, M., Jr.; Zemkova, D.; Vavrova, V.; Vlietinck, R.; Cassiman, J.-J.; Cuppens, H. Polymorphisms in the Mannose Binding Lectin Gene Affect the Cystic Fibrosis Pulmonary Phenotype. J. Med. Genet. 2004, 41, 629-633. [CrossRef]

23. Laisk, T.; Peters, M.; Saare, M.; Haller-Kikkatalo, K.; Karro, H.; Salumets, A. Association of CCR5, TLR2, TLR4 and MBL Genetic Variations with Genital Tract Infections and Tubal Factor Infertility. J. Reprod. Immunol. 2010, 87, 74-81. [CrossRef]

24. Tarova, E.T.; Polakova, H.; Kayserova, H.; Celec, P.; Zuzulova, M.; Kadasi, L. Study of the Effect of DNA Polymorphisms in the Mannose-Binding Lectin Gene (MBL2) on Disease Severity in Slovak Cystic Fibrosis Patients. Gen. Physiol. Biophys. 2012, 30, 373-378. [CrossRef]

25. Sokołowska, A.; Świerzko, A.S.; Gajek, G.; Gołos, A.; Michalski, M.; Nowicki, M.; Szala-Poździej, A.; Wolska-Washer, A.; Brzezińska, O.; Wierzbowska, A.; et al. Associations of Ficolins and Mannose-Binding Lectin with Acute Myeloid Leukaemia in Adults. Sci. Rep. 2020, 10, 10561. [CrossRef] [PubMed]

26. Swale, A.; Miyajima, F.; Kolamunnage-Dona, R.; Roberts, P.; Little, M.; Beeching, N.J.; Beadsworth, M.B.J.; Liloglou, T.; Pirmohamed, M. Serum Mannose-Binding Lectin Concentration, but Not Genotype, Is Associated With Clostridium Difficile Infection Recurrence: A Prospective Cohort Study. Clin. Infect. Dis. 2014, 59, 1429-1436. [CrossRef] [PubMed]

27. Madsen, E.C.; Levy, E.R.; Madden, K.; Agan, A.A.; Sullivan, R.M.; Graham, D.A.; Randolph, A.G. Mannose-Binding Lectin Levels in Critically Ill Children With Severe Infections. Pediatr. Crit. Care Med. 2017, 18, 103-111. [CrossRef] [PubMed]

28. Su, C.; Lin, Y.; Cai, L.; Mao, Q.; Niu, J. Association between Mannose-Binding Lectin Variants, Haplotypes and Risk of Hepatocellular Carcinoma: A Case-Control Study. Sci. Rep. 2016, 6, 32147. [CrossRef]

29. Puente, M.; Fariñas-Alvarez, C.; Moreto, A.; Sánchez-Velasco, P.; Ocejo-Vinyals, J.G.; Fariñas, M.C.; on behalf of SCT Team. Low Pre-Transplant Levels of Mannose-Binding Lectin Are Associated with Viral Infections and Mortality after Haematopoietic Allogeneic Stem Cell Transplantation. BMC Immunol. 2019, 20, 40. [CrossRef]

30. Kalia, N.; Singh, J.; Sharma, S.; Arora, H.; Kaur, M. Genetic and Phenotypic Screening of Mannose-Binding Lectin in Relation to Risk of Recurrent Vulvovaginal Infections in Women of North India: A Prospective Cohort Study. Front. Microbiol. 2017, 8. [CrossRef] 
31. Losada López, I.; García Gasalla, M.; González Moreno, J.; Serrano, A.; Domínguez Valdés, F.J.; Milà, J.; Payeras, A. Mannose Binding Lectin Polymorphisms in Systemic Lupus Erythematosus in Spain. Eur. J. Inflamm. 2016, 14, 78-85. [CrossRef]

32. Pagowska-Klimek, I.; Świerzko, A.S.; Michalski, M.; Moll, M.; Szala-Poździej, A.; Sokołowska, A.; Krajewski, W.R.; Cedzyński, M. Mannose-Binding Lectin (MBL) Insufficiency Protects against the Development of Systemic Inflammatory Response after Pediatric Cardiac Surgery. Immunobiology 2016, 221, 175-181. [CrossRef]

33. Gu, X.; Ji, Q.; Wang, H.; Jiang, M.; Yang, J.; Fang, M.; Wang, M.; Gao, C. Genetic Variants of Mannose-Binding Lectin 2 Gene Influence Progression and Prognosis of Patients with Hepatitis B Virus Infection in China. Clin. Res. Hepatol. Gastroenterol. 2016, 40, 614-621. [CrossRef] [PubMed]

34. Monsey, L.; Best, L.G.; Zhu, J.; DeCroo, S.; Anderson, M.Z. The Association of Mannose Binding Lectin Genotype and Immune Response to Chlamydia Pneumoniae: The Strong Heart Study. PLoS ONE 2019, 14, e0210640. [CrossRef] [PubMed]

35. Amiri, A.; Sabooteh, T.; Shahsavar, F.; Anbari, K.; Pouremadi, F. Mannose-Binding Lectin (MBL) Gene Polymorphisms in Susceptibility to Pulmonary Tuberculosis among the Lur Population of Lorestan Province of Iran. Genom. Data 2017, 12, 146-150. [CrossRef] [PubMed]

36. Ouyang, Y.; Zhu, L.; Shi, M.; Yu, S.; Jin, Y.; Wang, Z.; Ma, J.; Yang, M.; Zhang, X.; Pan, X.; et al. A Rare Genetic Defect of MBL2 Increased the Risk for Progression of IgA Nephropathy. Front. Immunol. 2019, 10, 537. [CrossRef]

37. Giang, N.T.; van Tong, H.; Quyet, D.; Hoan, N.X.; Nghia, T.H.; Nam, N.M.; Hung, H.V.; Anh, D.T.; Van Mao, C.; Son, H.A.; et al. Complement Protein Levels and MBL2 Polymorphisms Are Associated with Dengue and Disease Severity. Sci. Rep. 2020, 10, 14923. [CrossRef] [PubMed]

38. Toivonen, L.; Vuononvirta, J.; Mertsola, J.; Waris, M.; He, Q.; Peltola, V. Polymorphisms of Mannose-Binding Lectin and Toll-like Receptors 2, 3, 4, 7 and 8 and the Risk of Respiratory Infections and Acute Otitis Media in Children. Pediatr. Infect. Dis. J. 2017, 36, e114-e122. [CrossRef] [PubMed]

39. Bujalkova, M.; Zavodna, K.; Krivulcik, T.; Ilencikova, D.; Wolf, B.; Kovac, M.; Karner-Hanusch, J.; Heinimann, K.; Marra, G.; Jiricny, J.; et al. Multiplex SNaPshot Genotyping for Detecting Loss of Heterozygosity in the Mismatch-Repair Genes MLH1 and MSH2 in Microsatellite-Unstable Tumors. Clin. Chem. 2008, 54, 1844-1854. [CrossRef]

40. Mehta, B.; Daniel, R.; Phillips, C.; McNevin, D. Forensically Relevant SNaPshot ${ }^{\circledR}$ Assays for Human DNA SNP Analysis: A Review. Int. J. Leg. Med. 2017, 131, 21-37. [CrossRef]

41. Garred, P.; Strøm, J.J.; Quist, L.; Taaning, E.; Madsen, H.O. Association of Mannose-Binding Lectin Polymorphisms with Sepsis and Fatal Outcome, in Patients with Systemic Inflammatory Response Syndrome. J. Infect. Dis. 2003, 188, 1394-1403. [CrossRef]

42. Skalníková, H.; Freiberger, T.; Chumchalová, J.; Grombiř́ková, H.; Šedivá, A. Cost-Effective Genotyping of Human MBL2 Gene Mutations Using Multiplex PCR. J. Immunol. Methods 2004, 295, 139-147. [CrossRef]

43. de Araujo, F.J.; Mesquita, T.G.; da Silva, L.D.O.; de Almeida, S.A.; de S Vital, W.; Chrusciak-Talhari, A.; de O Guerra, J.A.; Talhari, S.; Ramasawmy, R. Functional Variations in MBL2 Gene Are Associated with Cutaneous Leishmaniasis in the Amazonas State of Brazil. Genes Immun. 2015, 16, 284-288. [CrossRef]

44. Speletas, M.; Gounaris, A.; Sevdali, E.; Kompoti, M.; Konstantinidi, K.; Sokou, R.; Tsitsami, E.; Germenis, A.E. MBL2 Genotypes and Their Associations with MBL Levels and NICU Morbidity in a Cohort of Greek Neonates. J. Immunol. Res. 2015, 2015, 1-10. [CrossRef] [PubMed]

45. Munthe-Fog, L.; Madsen, H.O.; Garred, P. Genotyping of FCN and MBL2 Polymorphisms Using Pyrosequencing. In The Complement System; Gadjeva, M., Ed.; Methods in Molecular Biology; Humana Press: Totowa, NJ, USA, 2014; Volume 1100, pp. 123-130. ISBN 978-1-62703-723-5.

46. Konopac, M.; Dusatkova, P.; Cinek, O. SNPman: A Program for Genotype Calling Using Run Data from TaqMan Allelic Discrimination. Bioinformatics 2011, 27, 2306-2308. [CrossRef]

47. Ito, T.; Inoue, E.; Kamatani, N. Association Test Algorithm Between a Qualitative Phenotype and a Haplotype or Haplotype Set Using Simultaneous Estimation of Haplotype Frequencies, Diplotype Configurations and Diplotype-Based Penetrances. Genetics 2004, 168, 2339-2348. [CrossRef] [PubMed]

48. Zuo, L.; Wang, K.; Luo, X. Use of Diplotypes-Matched Haplotype Pairs from Homologous Chromosomes-in Gene-Disease Association Studies. Shanghai Arch. Psychiatry 2014, 26, 165-170. [CrossRef]

49. Tsujimoto, S.; Osumi, T.; Uchiyama, M.; Shirai, R.; Moriyama, T.; Nishii, R.; Yamada, Y.; Kudo, K.; Sekiguchi, M.; Arakawa, Y.; et al. Diplotype Analysis of NUDT15 Variants and 6-Mercaptopurine Sensitivity in Pediatric Lymphoid Neoplasms. Leukemia 2018, 32, 2710-2714. [CrossRef]

50. Al Bkhetan, Z.; Zobel, J.; Kowalczyk, A.; Verspoor, K.; Goudey, B. Exploring Effective Approaches for Haplotype Block Phasing. BMC Bioinform. 2019, 20, 540. [CrossRef]

51. Browning, S.R.; Browning, B.L. Haplotype Phasing: Existing Methods and New Developments. Nat. Rev. Genet. 2011, 12, 703-714. [CrossRef] [PubMed]

52. Purcell, S.; Neale, B.; Todd-Brown, K.; Thomas, L.; Ferreira, M.A.R.; Bender, D.; Maller, J.; Sklar, P.; de Bakker, P.I.W.; Daly, M.J.; et al. PLINK: A Tool Set for Whole-Genome Association and Population-Based Linkage Analyses. Am. J. Hum. Genet. 2007, 81, 559-575. [CrossRef]

53. Excoffier, L.; Lischer, H.E.L. Arlequin Suite Ver 3.5: A New Series of Programs to Perform Population Genetics Analyses under Linux and Windows. Mol. Ecol. Resour. 2010, 10, 564-567. [CrossRef] 
54. Kim, S.; Park, K.; Shin, C.; Cho, N.H.; Ko, J.-J.; Koh, I.; Kwack, K. Diplotyper: Diplotype-Based Association Analysis. BMC Med. Genom. 2013, 6, S5. [CrossRef] [PubMed]

55. Kavrikova, D.; Borilova Linhartova, P.; Lucanova, S.; Poskerova, H.; Fassmann, A.; Izakovicova Holla, L. Chemokine Receptor 2 (CXCR2) Gene Variants and Their Association with Periodontal Bacteria in Patients with Chronic Periodontitis. Mediat. Inflamm. 2019, 2019, 1-8. [CrossRef] [PubMed] 